apuntesuniversitarios.upeu.edu.pe

Apuntes Universitarios, 2020: 10(3), julio-setiembre

ISSN: 2304-0335 DOI: https://doi.org/10.17162/au.v10i3.477

\title{
Ecosistema de información relacionado con el monitoreo del estilo de vida saludable de los adultos
}

\section{Information ecosystem related to adults` healthy lifestyle monitoring}

\author{
Oleg A. Musin, ${ }^{1 \text { a }}$ Elena V. Bystritskaya, ${ }^{2}$ Yuri S. Zhemchug, ${ }^{3}$ Vasiliy V. Sokolov, ${ }^{4}$ \\ Igor Y. Gryaznov ${ }^{5}$ y Timofey A. Savchenko ${ }^{6}$ \\ Nizhny Novgorod State Pedagogical University, Nizhny Novgorod, Rusia ${ }^{12345}$ \\ Privolzhsky Research Medical University, Nizhny Novgorod, Rusia ${ }^{6}$
}

(iD) Orcid ID: https $/ /$ orcid.org/0000-0001-8407-1700

iD Orcid ID: https://orcid.org/0000-0003-1873-86202

iD Orcid ID: https $/ /$ orcid.org/0000-0003-4893-71533

iD Orcid ID: https://orcid.org/0000-0003-2245-23854

Orcid ID: https $/ /$ orcid.org/0000-0001-5219-7413

Orcid ID: https://orcid.org/0000-0003-0379-40056

Recibido: 08 de enero 2020

Aceptado: 15 de junio 2020

\begin{abstract}
Resumen
Este artículo analiza el problema de proporcionar a los adultos información confiable, relevante y oportuna que les permita organizar sus actividades: el régimen de trabajo y descanso de acuerdo con los objetivos de un estilo de vida saludable y la corrección de la salud. El objetivo es determinar los criterios y componentes de un recurso de información que será adecuado para los objetivos de mantener la salud de los adultos. Los enfoques principales para la investigación de los medios de comunicación de atención médica son: enfoques estructural-analíticos, orientados a la personalidad y culturales. Métodos de investigación: análisis y síntesis de la literatura científica y metodológica y el entorno de información sobre los problemas de mejora de la salud de la población y métodos de procesamiento de datos matemáticos. El artículo presenta los resultados de la determinación de los criterios para monitorear el ecosistema de información en un estilo de vida saludable, entre estos criterios se identificaron los siguientes: la validez científica de la información, la focalización, la importancia social y el diálogo. Además, se identificaron portales de datos que contribuyen a la solución de ciertas tareas de mejora de la salud de la población adulta. Los autores diseñaron e implementaron el portal informativo y educativo "3 jóvenes" que está dirigido a la implementación integrada de las necesidades básicas de mejora de la salud de la población adulta, teniendo en cuenta
\end{abstract}

${ }^{\mathrm{a} C o r r e s p o n d e n c i a ~ a l ~ a u t o r ~}$

E-mail: mysin332@mail.ru 
la interconexión de los componentes de salud: física, mental y social. Se presentan y discuten los resultados que prueban la efectividad del uso del portal de los autores para garantizar un estilo de vida saludable para los adultos. El artículo será útil para adultos que desean llevar un estilo de vida saludable con el apoyo de los recursos de información, maestros y formadores que trabajan con personas de edad madura. Este artículo también es útil para los maestros de la Facultad de Educación Física que planean promover un estilo de vida saludable entre las diferentes categorías de edad. El portal también será útil en el sistema de educación profesional adicional de instructores y entrenadores de fitness. La novedad de la investigación del autor consiste en la aplicación de enfoques metodológicos y criterios con base científica para monitorear el ecosistema de información relacionado con la organización de un estilo de vida saludable para adultos; en el desarrollo y prueba de un portal de información que resuelve un complejo de tareas para garantizar un estilo de vida saludable para los adultos.

Palabras clave: personas de edad madura, adultos, estilo de vida saludable, informac ión y entorno educativo, portal de información, potencial de las TIC, entorno de información, composición de componentes del ecosistema de información, modelo de portal de información.

\begin{abstract}
This article discusses the problem of providing adults with reliable, relevant and timely information that allows them to organize their activities: the regime of work and rest in accordance with the goals of a healthy lifestyle and health correction. The goal is to determine the criteria and components of an information resource that will be adequate to the goals of keeping health of adults. The leading approaches to the health care mass media research are: structural-analytical, personality-oriented and cultural approaches. Research methods: analysis and synthesis of scientific and methodological literature and the information environment on the problems of the population health improving and methods of mathematical data processing. The article presents the results of determining the criteria for monitoring the information ecosystem on a healthy lifestyle, among these criteria the following were identified: the scientific validity of information, targeting, social significance and dialogue. Also, data portals that contribute to the solution of certain tasks of the adult population health improving were identified. The authors designed and implemented the informational and educational portal " 3 youth" which is aimed at the integrated implementation of the basic health-improving needs of the adult population, taking into account the interconnection of health components: physical, mental, social. The results proving the effectiveness of using the authors' portal to ensure a healthy lifestyle for adults are presented and discussed. The article will be useful to adults who want to lead a healthy lifestyle with the support of the information resources, teachers and trainers working with people of mature age. This article is also useful for teachers of the Faculty of Physical Education who plan to promote a healthy lifestyle among different age categories.
\end{abstract}

Keywords: persons of mature age, adults, healthy lifestyle, information and educational environment, information portal, ICT potential, information environment, information ecosystem component composition, information portal model.

\title{
Introduction
}


This study is considered acute due to the fact that now more and more adults are solving the problems of their recovery using internet resources which include specialized sites, non-specialized sites, the blogosphere and, to a lesser extent, electronic libraries, systematic scientific and methodological journals. Thus, the research problem associated with the need to monitor internet resources for a healthy lifestyle and the formation of new information and educational portals containing reliable and useful information is extremely acute (Martsinkovskaya, 2012; Vichugova et al., 2012). This fact is confirmed by a number of studies. This way there is a need to accompany the use of these resources for people of mature age, which will contain elements of coaching, tutoring, patronage, and other effective forms of educational activity. Thus, the internet resource aimed at educating adults in the field of a healthy lifestyle and containing reliable scientificallybased information should also include elements of pedagogical support for the implementation of the recommendations presented in the resource and aimed at keeping health, creating a health culture and correcting the bodily, emotional, mental and socially personal components of health (Kiseleva, Valetov \& Shlyapnikova, 2019).

The issues of constructing healthy lifestyles and designing educational routes for those involved are widely considered by scientists, mainly in relation to children of adolescents and youngsters (Arkhipova et al., 2019). Despite great experience in life adults do not always understand correctly the principles of healthy lifestyle, adequate mechanisms for its implementation and methods that relate to health saving and health formation, which are described in a number of scientific and scientific-methodological works. The interest of the immediate environment in including the person in the healthy lifestyle space is also important for the formation of a healthy lifestyle of adults. Also, an important aspect of attracting a person to a healthy lifestyle is his professional activity and the status of a healthy person in that professional environment where the person is. This aspect of human health care has been considered. Based on the facts mentioned, we can conclude that adults do not have enough time to carefully analyze information on healthy lifestyle issues and they need ready-made tips that can be quickly obtained in the public domain (Kochneva \& Grishina, 2019; Ozerina, Suvorova \& Dmitrieva, 2019; Tatarinov, 2019).

There is a really large range of information sources on the internet that meet the requirements for reliability and other criteria set forth in the works (Agafonova, 2016). The authors also mention the phenomenon of the gullibility of mature people in a kind of "magic pill". Scientists (Sukhodolov, Kuznetsova \& Timofeev, 2017) are busy with the 
debunking of myths cited in various internet sources. But these and other authors did not consider the application of methodological approaches to monitoring information portals that provide information on a healthy lifestyle for people of mature age (Grabar \& Sokolovskaya, 2012; Wegner et al., 2016). Also, in the authors' works, only certain selection criteria are given for information that can accompany the process of maintaining a healthy lifestyle for adults. It is practically unknown about information portals that would carry an educational function in maintaining a healthy lifestyle for people of mature age and that would be formed on the basis of a set of scientifically based criteria (Mali, 2014; Vorobyova \& Koroeva, 2019; Sheykh, \& Emadian, 2019). Thus, the research problems consist in finding the ways and means of creating new information portals to support a healthy lifestyle of adults, taking into account their interests and needs and on the basis of a set of scientifically based criteria.

Therefore the aim of the study is to monitor the ecosystem information associated with a healthy lifestyle of adults and, on its basis, to identify criteria that an information resource, that helps people of mature age to lead a healthy lifestyle, must meet, as well as the definition of components and the development of an information and educational resource in accordance with the identified criteria (Mikerova \& Shvets, 2015; Novikova, 2015; Abbasi, \& Heirani, 2019).

\section{Literature review}

There are many sites aimed at providing information about a healthy lifestyle of different degrees of authenticity (Agafonova, 2016). The authors of these sites and blogs are people with personal, individual experience as a rule, in the successful implementation of health-forming technologies (Osik, 2012). Such work does not represent a single system that would consider the goals and needs of each recipient (Gadzhimuradova \& Agalarova, 2014). At the same time, many of the mentioned internet resources contain useful information on inclusion in physical activity, in active life, proper nutrition and other components of health saving (Grabar \& Sokolovskaya, 2012).

Unlike science-based sources presented in manuals, articles, materials of scientific conferences, internet allows false information to penetrate into it, as it is often created by non-specialists and is not reviewed (Izvozchikov, Sokolova \&Tumale va, 2000). Many scientists say that there is a need to form an image of censorship of those sites, blogs that are focused on training (Fedorov, Paputkova \& Samerkhanova, 2018). The following reasons for the false information to enter the structure of meaningful 
support for a healthy lifestyle may be distinguished (Kochneva \& Grishina, 2019):

1. simplicity of access to information portals for all categories of persons;

2. desire on the basis of a "pill for everything" or practice of "miraculous healing" using the trustfulness of respondents and their tendency to searching for easy ways to solve complex health problems, on the basis of acquiring personal benefit;

3. the lack of specialists attention to the popularization of objective and scientifically sound information in the field of a healthy lifestyle in the scientific community.

In order to include people of mature age in a favorable information environment that satisfies their needs, we set and solved a number of the following tasks (Mali, 2014):

- monitoring of available information resources on a healthy lifestyle for adults;

- determining the needs of a mature person for a healthy lifestyle;

- development of components based on the identified needs of the Health Conservation Information Portal;

- expertise of the developed portal components both from the sides: the focus group and the involved experts who are specialists in various areas of health saving;

- comparison of analysis of expert assessment results and focus group assessment.

Based on the literature review briefly reviewed above, the authors identified criteria for further monitoring of internet resources related to the formation and correction of adult health, which later became the basis for the creation and evaluation of the educational information portal (Dmitriev \& Zagrevskaya, 2018). The most important criteria are the following (Martsinkovskaya, 2012):

- scientific validity of information - information search should be based on the generalization of a large array of experimental data;

- targeting - information should correspond to the needs for a healthy lifestyle of a certain target audience and satisfy these needs by presenting recommendations in an accessible language;

- social significance - the goals of presenting information must correspond to social values and development trends of society, must meet the challenge of time and social order;

- dialogue - information should include motivational components aimed at a 
given audience and meet its interests, as well as significant elements of interactive methods of education and elements of feedback.

\section{Methodological framework}

In the framework of this study a conceptual system was developed. Information resource - an object located in an electronic environment where information on a topic of interest is collected. The component composition of the informational educational portal on healthy lifestyles is the structure of the informational resource, each element of which reflects one or more needs of adults associated with the formation of physical, mental and social-personal health and necessary for their successful involvement in the information environment for a healthy lifestyle (Izvozchikov, Sokolova \& Tumaleva, 2000; Saveliev, 2019).

Work hypothesis: we assume that the developed information resource of healthforming technologies will satisfy the existing interest of users, as well as create new needs and introducing them into a healthy lifestyle. The following methodological approaches were used to monitor information resources related to a healthy lifestyle and to develop the resource.

- structural and analytical - involves the decomposition of a healthy lifestyle system into individual components that correspond to the logic of building health as an object of study and analysis of the principles, methods, techniques and results of achieving harmonious, physical, mental and social health;

- personality-oriented - this is the orientation of the information and educational portal on the development and self-development of the adult personality qualities, his creative abilities and capabilities based on the humanistic values of health, labor, personality, friendship, etc. This approach implies treating the subject as a responsible subject of his own self-development and self-education.

- cultural approach - implies the harmonization of the personal interests of small reference groups such as the family and the professional environment, as well as society in the structure of creative activity with the leading role of sociocultural processes and phenomena.

The integrated application of these approaches allows us to assess if the target, substantial, technological and effective components of information resources meet the requirements of integral and differential reliability, objective and subjective novelty of 
information and solving problems of forming a harmoniously developed personality within the framework of an active adult generation (Bystritskaya et al., 2019).

\section{Research methods}

Comparative analysis, the target audience survey, psychological and physical tests for representatives of the focus group, the method of pedagogical experiment, the method of graphical interpretation of data and mathematical statistics.

\section{Results}

Based on the approaches mentioned above, using the identified criteria and methods, the most popular adult portals related to maintaining a healthy lifestyle were monitored. Monitoring was conducted during the 2017-2018 academic year. The research base was made up of regular sites, periodical online publications on a healthy lifestyle, and a review of the blogging sphere was also conducted (Akimova \& Pashkin, 2006; Gadzhimuradova \& Agalarova, 2014). As a result, it was decided to present the educational information portal in the form of a website. In this regard, this article provides a detailed overview of the tasks of the structure and content of the sites associated with maintaining a healthy lifestyle by adults.

As an example, we consider the components of the information site Health with Elena Malysheva, one of the most popular programs, Live Healthy, A Portal about a Healthy Lifestyle, and Live. The site presents a variety of projects on a healthy lifestyle, examines diseases, presents medical articles, drug reference, etc. The composition of the current information resource "Health with Elena Malysheva":

- Website - "Health with Elena Malysheva".

- Orientation - presentation of information about various diseases.

- Content - an extensive set of various ailments and diseases with a brief description of them, weight loss programs, information about medications, medical research articles.

Names of sections and their contents:

- "Special Projects" - medical information about diseases;

- "Get rid of excess" - commercial programs aimed at losing weight;

- "Diseases" - information about various types of diseases;

- "Medicine" - information about medicines and medical institutions; 
- "Symptom Map" - a quick way to determine an existing ailment;

- "Television" - Health Programs.

The disadvantage of this resource is the absence of an open platform for discussing issues of a healthy lifestyle and a free complex of physical exercises of different levels on the basis of fitness. The advantages of the analyzed healthy lifestyle information portals are as follows:

1. Extensive data on various existing types of diseases;

2. Selected balanced diets for different audience portals;

3. The rules of personal hygiene, the implementation of physical exercises and the principles of a healthy lifestyle are structurally presented;

4. Sources citing medical articles;

5. Bright and colorful presentation of information.

In general, the component composition of these sites is the basis for the development of such an integrative product that would allow considering the results of the above analysis of existing information products on this topic for people in the labor and post-labor age. The components which are not completely represented on healthy lifestyle portals:

1. The absence of ways to prevent diseases;

2. The absence of complexes of physical exercises of different directions;

3. The absence of a platform for discussing various topics of healthy lifestyle;

4. Lack of information about recipes, products, ways to strengthen the body.

Also, a significant drawback of the site is the incomplete use of the potential of ICT, which provides a modern level of development of computer technology. Certainly, the presence of such sites has a beneficial effect on the formation of the information space of a healthy lifestyle, but it is important for us to create such conditions under which an ordinary user could enter the information environment and find the section he is interested in, without outside advertising and click through the labyrinth of links.

However, among the disadvantages in the structure and content of information and educational sites, we can accentuate the lack of a clear separation of the direction of the proposed information. This drawback arose due to the fact that website developers are trying to reach the widest possible audience by including different segments of the population. These portals offer general information without focusing on a specific age 
period. Therefore, when developing such resources, it is necessary to take into account age, sociocultural, professional, communicative, features of persons who are the focus of a group of users. Sections of sites consist of generally accepted recommendations on what and how to do, but there is no connection with individual, age, physiological and psychophysiological characteristics.

At the second stage of the study, the needs of adults were identified using a questionnaire consisting of a 3-level component:

Level 1 - revealing the level of knowledge about a healthy lifestyle;

Level 2 - determining the degree of involvement in the process of health saving;

Level 3 - clarification of the basic needs of mature people necessary for their successful involvement in this environment.

As a result of the experiment, the following data was obtained:

- Mature people have basic knowledge of a healthy lifestyle;

- Only $30 \%$ of respondents actively lead a healthy lifestyle;

- The main need of adults is reliable information provided in an accessible form, taking into account their age, physical, psychological and social spiritual characteristics.

Based on a comparative analysis of information resources and questioning of adults, the components of the content of the interactive resource were identified, as well as the technology of presenting the material adapted to the needs and abilities of people of mature age. Informational educational resource "3 youth" consists of interconnected components aimed at mature people.

1. Mental self-attitude - includes information about all kinds of fears and misconceptions associated with a healthy lifestyle.

2. Useful information - provides users with verified and high-quality information on proper nutrition, useful rules for maintaining a healthy lifestyle that positively affect the body of various sports, information on how to choose the right personal trainer and a number of other meaningful industries.

3. Training program - includes proven sets of exercises selected considering agerelated features, existing diseases or injuries to maintain a healthy state of your body, increase muscle tone and also the general emotional state.

4. Feedback - consists of 2 sections: in the first section, respondents ask their questions to experts and receive a timely answer, in the second section they create 
various topics in which they discuss emerging issues, share their own experience, and expand their information horizons.

Thus, for the formation of an adequate information space, it is necessary to include adults in the information environment for which there are various courses, but we have made an affordable product for any user.

One of the acquired goals of our website is: expanding consciousness, the sphere of communication, increasing working capacity, lengthening the age of maturity, the formation of new positive habits, information security, the ability to distinguish false information from useful information (Stafeeva et al., 2019). Due to the component composition of our site on one hand we satisfy the existing interest of users, and on the other hand we form new needs: the need for new activities, desired sports, biomechanical fundamentals of movement, the use of ordinary movements in everyday life, communication with an interested circle of people, etc. The formative research phase was conducted in the 2018-2019 academic year. The experiment involved 36 people.

At this stage of the study, participants in the focus group and expert group were invited to evaluate the component composition of the information resource for the implementation of health-saving technologies for adults according to the proposed criteria. The assessment was carried out on a five-point scale. Evaluation indicators of the electronic - educational resource " 3 youth" were carried out according to the calculation of the Pearson correlation criterion. The calculation data was obtained using the computer program Microsoft Office Excel 2010.

Table 1. Expert Assessment Indicators

\begin{tabular}{llll}
\hline Indicator & Expert Assessment & $\begin{array}{l}\text { Focus } \\
\text { Assessment }\end{array}$ & Group \\
\hline Sections & 4,24 & 5 \\
Design & 2,1 & 2,3 \\
Compliance of the proposed & 4,8 & 4,99 \\
information with the selected age & \\
group & 4,75 & \\
Ease of use & 4,92 & 4,75 \\
Variety of material & 4,8 \\
\hline
\end{tabular}

One of the most significant components, the experts chose the correspondence of 
the proposed information of the selected age group and the variety of material, to a lesser extent, the experts are satisfied with the design of the electronic educational portal. The focus group was least satisfied with the design as well as the experts, the rest were completely satisfied. The value of the Pearson correlation coefficient was 0.91 , which corresponds to the high tightness of the relationship between the expert assessment and the focus group assessment. This correlation is statistically significant at $\mathrm{p}<0.01$.

\section{Discussions}

Based on the monitoring of available information portals on a healthy lifestyle and identifying the needs of adults, the following conclusions were obtained:

- The main need for a healthy lifestyle is the availability of reliable information, considering physical, mental and social characteristics. These results are consistent with the research of Fedorov, Paputkova \& Samerkhanova (2018), Gadzhimuradova \& Agalarova (2014), Grabar \& Sokolovskaya (2012) and Izvozchikov, Sokolova \&Tumaleva (2000).

- Content components should reflect their essence in a simple way. These results are consistent with the research of Agafonova (2016), Akimova \& Pashkin (2006), Dmitriev \& Zagrevskaya (2018) and Kochneva \& Grishina (2019).

- When designing such information resources, it is necessary to take into account the needs of the people for whom the resource is being developed. These results are consistent with the research of Mali (2014), Martsinkovskaya (2012) and Osik (2012).

From our point of view, it is the health-improving orientation of a healthy lifestyle in combination with innovative technologies that will achieve the expected result: to form a need for new types of motor actions, communication with an interested circle of people, familiarizing with previously unknown sports, developing a habit of caring for your body, and raising level of physical fitness, to become more psychologically stable, as well as to adapt to the rapidly changing conditions of modern society (Osik , 2012; Zhemchug et al., 2019). Monitoring of the available information resources on a healthy lifestyle of adults has been carried out very thoroughly, the goal has been achieved, the tasks have been solved, the reliability of the working hypothesis has been proved.

\section{Conclusion}


The authors identified the basic needs of adults necessary for the formation of a positive attitude towards a healthy lifestyle and their inclusion in this space. Technologies of a healthy lifestyle that are most successfully applied and adapted for adults have been selected to consider all the individual characteristics of this age group. As the study showed, despite a significant number of studies, monitoring of the information space on the issue is not carried out systematically and not regularly (Markova et al., 2019; Fedorov, Paputkova \& Samerkhanova, 2018). The monitoring system developed by the authors on the basis of scientific approaches and the system of scientifically based criteria makes this process of informing the target audience about the basics of healthy lifestyle more effective.

Based on the above approaches and criteria, a resource has been developed that includes the specified component in the framework of which it is possible to realize and respond the needs of the persons for whom the resource is developed (Dmitriev \& Zagrevskaya, 2018). The developed resource will continue to be saturated with healthsaving technologies for adults, taking into account, among other things, the interests of the professional sphere and other areas of employment of people of mature age.

It is quite obvious that the accumulated experience in introducing health-saving educational technologies and health-saving technologies of the family requires summarizing, detailed analysis, joining the efforts of the state, social institutions, and the public to form a healthy family. This is the prospect of further research by the authors.

\section{Recommendations}

Possession of knowledge about the problems identified by the authors, methods of solving them will increase the efficiency of a specialist in the field of healthy lifestyle, who in his future professional activities will deal with the issue of health care for adults (Vorobyova \& Koroeva, 2019). In this connection, the scientifically based criterion base developed by the authors for monitoring information and educational resources on healthy lifestyle issues can provide significant assistance to both specialists and individuals who wish to be involved in this type of activity.

Moreover, this knowledge in their work can be used by university teachers engaged in the implementation of physical-health-improving and sports-mass work, for adults as well as in preparing students. This information is useful for teachers of continuing education courses, which are designed to quickly respond with the content of their activities to the needs arising from educators working with adults. 
In addition, the article will be useful for adults themselves who want to lead a healthy lifestyle with the support of the information environment. The developed portal will also be useful in the system of additional professional education of fitness instructors and trainers.

\section{References}

Agafonova, M. S. (2016). Sustainability of the functioning of the health sector. Scientific and methodological electronic journal "Concept", 2, 306-310.

Akimova, G. P. \& Pashkin, M. A. (2006). An analytical approach to solving the problem of monitoring the information space. High Availability Systems, 2, 44-50.

Arkhipova, M. V., Belova, E. E., Gavrikova, Y. A., Pleskanyuk, T. N. \& Arkhipov, A. N. (2019). Reaching Generation Z. Attitude Toward Technology Among the Newest Generation of School Students. Perspectives on the use of new information and communication technology (ict) in the modern economy. Book Series: Advances in Intelligent Systems and Computing, 726, 1026-1032.

Abbasi, A., \& Heirani, F. (2019). Investigate the relationship between value creation activities in intellectual capital with different business models in Isfahan carpet manufacturing companies. Journal of management and accounting studies, 7(02), $15-18$.

Bystritskaya, E. V., Ivanova, S. S., Burkhanova, I. Y., Stafeeva, A. V., Vorobyov, N. B., Romanova, A. A. \& Samedov, R. A. (2019). Technology of Accounting for Migrant Students' Needs in Physical Culture Bachelors' Education. International journal of applied exercise physiology, 8(2), 648-655.

Dmitriev, S. V. \& Zagrevskaya, A. I. (2018). Semantic planning of motor task solutions in the context of ontodidactics. Tomsk State University Journal, 427, 184-190.

Fedorov, A. A., Paputkova, G. A. \& Samerkhanova, E. K. (2018). New Design of University Educational Ecosystem in the Context of Modernisation of Teacher Education in Russia. Psikhologicheskaya nauka $i$ obrazovanie-psychological science and education, 23, 52-63.

Gadzhimuradova, Z. G., Agalarova, L. S. (2014). The study of factors affecting the formation of a healthy lifestyle of the urban population. Ural Medical Journal, 6(120), 79-84.

Grabar, N. G. \& Sokolovskaya, T. B. (2012). Modern information space and the formation of innovative needs of users. Scientific and technical libraries, 12, 13-16. 
Izvozchikov, V. V., Sokolova, G. Y., Tumaleva, E. A. (2000). The Internet as a component of the information picture of the world and the global educational information space. Science and School, 4, 15-23.

Kiseleva, Z. V., Valetov, M. R. \& Shlyapnikova, V. V. (2019). Health-saving education resources of the Orenburg region. Azimuth of scientific research: pedagogy and psychology, 3(28), 115-118.

Kochneva, E. M. \& Grishina, A. V. (2019). On the creation of a model of psychological and pedagogical support of positive parenthood. Vestnik of Minin University, 7(3), $10-21$.

Mali, N. A. (2014). Social health as a component of human psychological health. Modern Education: Scientific Approaches, Experience, Problems, Prospects. Proceedings of the X International Scientific and Practical Conference, pp. 192194.

Markova, S. M., Zanfir, L. N., Vaganova, O. I., Smirnova, Z. V. \& Tsyplakova, S. A. (2019). Department of educational process in conditions of implementation of interactive training of future engineers. Amazonia investiga, 8(18), 450-460.

Martsinkovskaya, T. D. (2012). Information socialization in a changing information space. Psychological Research, 5(26), 7-17.

Mikerova, G. Z. \& Shvets, E. P. (2015). The use of health-saving technologies in the family education of schoolchildren. Modern high technology, 12, 521-524.

Novikova, I. M. (2015). Variative approaches to the problem of a healthy lifestyle. Modern problems of science and education, 5, 135-145.

Osik, V. I. (2012). Human health and quality of life - the main problem of our time. Economics. Right. Print. Bulletin of XCEI, 2(23), 234-238.

Ozerina, A. A., Suvorova, O. V. \& Dmitrieva, E. E. (2019). Representations of the life path of women in late adulthood. Vestnik of Minin University, 7(1), 8-15.

Saveliev, Y. I. (2019). The influence of the media on the formation of motivation for fitness. young researcher: from idea to project. Materials of the III student scientificpractical conference, pp 267-268

Stafeeva, A. V., Vorobyov, N. B., Burkhanova, I. Y., Ivanova, S. S., Zhemchug, Y. S., Salnikova, E. A. \& Anfilova, N. A. (2019). Modern Approaches to Organizing the Evaluation of Trainee Teachers' Academic Achievements. Internationaljournal of applied exercise physiology, 8(2), 183-189.

Sukhodolov, A. P., Kuznetsova, I. A. \& Timofeev, S. V. (2017). Analysis of approaches 
in modeling media. Issues of theory and practice of journalism, 6(3), 287-305.

Sheykh, S. F. M., \& Emadian, S. O. (2019). Investigating the relationship between the conflict resolution skills among couples on the level of marital conflict and their mental health. Journal of Social Sciences and Humanities Research, 7(02), 15-21.

Tatarinov, K. A. (2019). Features of building a line of information products in Russian online education. Azimuth of scientific research: pedagogy and psychology, 8(26), 254-257.

Vichugova, A. A., Vichugov, V. N., Tsapko, S. G., Dmitrieva, E. A. (2012). Methods and means of integrating information systems within a single information space. Systems for design, technological preparation of production and management of the stages of the life cycle of an industrial product (CAD / CAM / PDM - 2012): Tr. XII Int. conf. Moscow: Analyst.

Vorobyova, I. N. \& Koroeva, T. B. (2019). Current Trends in Students' Healthy Lifestyle. Azimuth of Scientific Research: Pedagogy and Psychology, 4(29), 48-50

Wegner, P. G., Polotnyanko, K. E., Ushakova, E. V., Khimicheva, N. A. (2016). The problem of forming a healthy lifestyle and the diversity of pedagogical management systems. Philosophy of Education, 5, 166-175

Zhemchug, Y. S., Sokolov, V. V., Gryaznov, I. Y., Musin, O. A., Lebedkina, M. V. \& Savchenko, T. A. (2019). The Issue of Gto (Ready for Labor and Defense) Program Implementation into the System of Higher Education of Nizhny Novgorod Region. International journal of applied exercise physiology, 8(2), 176-182. 